DOI: 10.20472/IAC.2019.052.062

\title{
COSTA SYNODINOS
}

North-West University, South Africa

KIRTY-LEE SHARP

Vaal University of Technology, South Africa

\section{ARE GENERATION Y STUDENTS BRAND LOYAL TO THEIR UNIVERSITY? A CASE OF ATTITUDE, COMMITMENT AND TRUST ON STUDENT BRAND LOYALTY}

\begin{abstract}
:
Customer loyalty is at the epicentre of any successful business. As such, the ultimate goal for any organisation is to create a loyal customer base. Loyalty occurs when organisations consistently satisfy the needs and wants of their customers. In addition, the more trust a consumer places in a particular organisation, the more loyal they will be to that organisation. Supportive attitudes and relationship commitment are perceived as valuable predeterminants when measuring customer loyalty and predicting future purchasing behaviour of consumers. Similarly, student loyalty is a major goal for a university. Loyal students engage in positive word of mouth marketing and could consider returning to their university to complete their postgraduate studies. This study aimed to determine if Generation Y students display both supportive attitudes towards their current university and if they possess some sort of relationship commitment towards their university. In addition, the study sought to understand the impact with which Generation Y students' trust exhibits towards brand loyalty of their respective universities. A total of 480 self-administered questionnaires were distributed across three higher education institutions in the Gauteng province of South Africa. A variety of statistical techniques were employed to analyse the captured data. These included internal-consistency reliability and validity measures, descriptive statistics and structural equation modelling. The study's results found Generation $Y$ students' supportive attitudes and their relationship commitment have a direct positive significant influence towards trust in their university. Moreover, the trust that Generation $Y$ students placed into their university has a direct positive influence on student brand loyalty. Based on the commitment-trust theory of relationship marketing, both relationship commitment and trust need to exist for relationships to be successful. The results indicate that relationship commitment and trust are cooperative behaviours that allow both Generation $Y$ students and universities to mutually fulfil their needs. Thus, Generation $Y$ students feel a sense of value, whilst, the university receives customer loyalty in return. The results of this study indicate that universities should take note of a student's supportive attitudes and relationship commitment. In addition, universities must take students' trust into consideration, as this affects student brand loyalty and ultimately student retention for the institution.
\end{abstract}

\section{Keywords:}

Relationship commitment, attitudes, trust, brand loyalty, Generation Y students, South Africa

JEL Classification: M31 


\section{Introduction}

Students who graduate from a particular Higher Education Institution (HEI) have numerous opportunities to offer continued support to the HEl they graduate from. This may include, but not be limited to, positive word-of-mouth to both current and prospective students, financial assistance and cooperative or community engagement via the university channels available to them (Ali, Zhou, Hussain, Nair \& Ragavan, 2016:75; Hanssen \& Solvoll, 2015:745 \& Alves \& Raposo, 2010:76). Rengel, Ramirez and Benavides (2017:753) suggest that at the core, loyalty is concerned with retaining current customers and acquiring new or prospective customers through recommendations. This is reiterated by Giner and Rillo (2016:2557), stating that retaining existing customers is just as important as attracting new or prospective customers.

Born between 1986 and 2005, the Generation Y cohort are individuals that have been born into a computer generation, making them tech-savvy, pragmatic, environmentally and socially aware, whilst at the same time open to new experiences (Markert, 2004:21; Noble, Hytko \& Phillips, 2009:618). Bevan-Dye and Surujlal (2011) theorise that the individuals of the Generation Y cohort have the capability to become trendsetters as a result of their tertiary education, which is believed to lead to better jobs and independent incomes (Schiffman \& Kanuk, 2014:341). This reiterates the importance of HEls to attract and retain students who are brand loyal. Owing to the large number of HEls currently available in South Africa for students to choose from, there is a significant need for research which investigates the factors that can both attract and retain students. Consequently, this study is aimed at identifying these underlying factors and investigating the influence these factors have on student brand loyalty.

\section{Literature review}

With regards to HEls, it is paramount to build brand loyalty. The more customers, in this case students, feel an emotional attachment to a particular HEI, the more likely they will be to make a commitment. These commitments could include admissions, donations, referrals or other positively associated actions (Hinds, 2017). Abbas (2019:54) indicates that HEls have access to several different touchpoints, which highlight numerous ways in which HEls can build loyalty. These include understanding the importance of creating efficient and effective educational services which will promote consistent and long-term brand loyalty, taking note of students' expectations based on their current demands as a result of the ever-changing environment students find themselves in and complying with respective accreditation authorities, both internationally and in South Africa. Hinds (2017) argues that the more HEls are able to take advantage of the numerous opportunities they have to build brand loyalty, the more committed and loyal the customers, namely students, will become. Similarly, student loyalty does not only provide a competitive advantage to HEls, but it is one of the key objectives of HEls. As such, HEls need to try their utmost best to meet students' expectations in an effort to keep them satisfied, which will go a long way in promoting supportive attitudes, relationship commitment, trust and loyalty (Thomas, 2011:183; Aritonang \& Lerbin, 2014:77).

Mpinganjira, Dos Santos, Botha, Du Toit, Erasmus, Maree and Mugobo (2014:127) define attitude as a broad term used to describe feelings, beliefs and behavioural intentions that individuals have towards a number of things which include, but are not limited to, brands, products, services, other 
individuals, issues and events. The feelings, beliefs and behavioural intentions influence the way individuals evaluate and respond to things. Roberts-Lombard and Parumasur (2017:6) add that attitudes are the consistent way in which consumers behave, which can be either favourable or unfavourable towards a brand, product, service, individual, issue or event. Schiffman and Kanuk (2014:194) highlight that attitudes are learnt, which indicates that the attitudes individuals have towards particular things are developed as a result of direct experience with a particular brand, product, service, individual, issue or event and information obtained from other individuals via word-of-mouth, the Internet, social media, direct marketing or mass-media advertising.

Roberts-Lombard and Parumasur (2017:325) suggest that by ensuring that an organisation's brand, product and/or service meets or exceeds customer expectations and that the performance is consistent and good, organisations will be able to develop customer loyalty by altering customer attitudes. Sung and Yang (2008:357) postulate that students' supportive attitudes represent their identification and commitment to a particular organisation, such as an HEI. A student's attitude, defined as a short-term form of student satisfaction, involves the evaluation of a student's educational experience from an HEI (Ali et al., 2016:74; Hanssen \& Solvoll, 2015:745; Petruzzellis \& Romanazzi, 2010:150). Given that satisfaction is commonly known as a factor which influences student loyalty, students may display positive intentions to be brand loyal towards their current HEI (Petruzzellis \& Romanazzi, 2010:150). This has been built based on the theory of reasoned action and theory of planned behaviour. These theories are commonly known to explain the relationship between attitude and loyalty (i.e. intention and behaviour) (Ajzen, 1991; Ajzen \& Fishbein, 1977; Fishbein \& Ajzen, 1975).

Roberts-Lombard and Parumasur (2017:294) define relationship commitment as the desire to develop a stable relationship. This requires a willingness to make short-term sacrifices in an effort to maintain the relationship and the confidence to maintain the stability of the relationship. Holford and White (1997:250) indicate that relationship commitment can be established between individuals or organisations. The higher the termination costs associated with relationships, the more superior the benefits are, or the more shared values there are between the partners in the relationship, the deeper the level of commitment. Baker (2001:421) proposes that relationship termination costs include all expected losses incurred as a result of terminating a particular relationship due to the presence of few to no comparable potential alternative partners, substantial switching costs or expenses associated with the disillusions of certain relationships. Holford and White (1997:25) suggest that the perceived costs associated with terminating a relationship between a student and an $\mathrm{HEl}$ might include the loss of friendships which were fostered at the $\mathrm{HEI}$, or the risk that the course credits earned at one $\mathrm{HEl}$ might not be acknowledged or accepted at another HEI. Spacey (2018) adds that the benefits customers receive from relationships are linked to the value associated with a brand, product and/ or service. Consequently, the value propositions that customers identify in a brand, product and/ or service restrict the associated customer benefits. In terms of HEls, students might be more willing to develop and maintain a relationship with an $\mathrm{HEl}$ if it offers a better combination of benefits, which could include the cost of education, fees, quality education and the location of the HEI (Holford \& White, 1997:250).

Kothari (2019) proposes that different types of consumers have different perceptions with regards to value and what is important to them. Lang (2016) indicates that trust and value are significant 
predictors of relationship commitment. While trust is the key to developing successful relationships, creating value is the guide which results in relationship commitment, which in turn ensures a future for relationships. Holdford and White (1997:250) indicate that partners within a relationship, both individuals or organisations, that share similar values regarding policies, goals and appropriate behaviour, are more likely to show relationship commitment. Students who have participated in some degree of professional socialisation, which involves students adopting ideals, goals and the codes of conduct set out by the HEls they attend, are more prone to developing and maintaining a relationship with an $\mathrm{HEI}$, opposed to students who view their chosen $\mathrm{HEI}$ or course as a mere means to gain employment.

According to Simson (2019), creating trust, building trust and keeping trust is paramount in any organisation. Without trust, it becomes very difficult for organisations to achieve anything. Consequently, trust is built when a customer's confidence in a brand, product and/ or service is constantly and consistently realised. Setyawan (2015:44) articulates that trust is an important factor that organisations need to take into consideration when building brand loyalty. Ahmed, Rizwan, Ahmad and Haq (2014:309) argue that trust assists with generating brand loyal customers and that without trust, brand loyalty is not possible.

Sung and Yang (2008:36) propose that there are significant benefits for HEls that build and maintain trust. The more students trust a particular HEI, the more likely those students will decide to choose that HEI or enrol at the HEI. The higher the level of trust, the greater the likelihood is that students will have positive experiences and evaluations with regards to the HEl. This will assist in generating positive word of mouth, increasing quality perceptions and reducing the degree of sensitivity students may experience with regards to changes in tuition and any other associated costs. There is a significant positive relationship found between trust and brand loyalty (Ahmed et al., 2014:309). This indicates that the more organisations meet or exceed the expectations of their customers, the more trust customers will have in the organisation and the easier it will be to create and retain loyal customers.

Roberts-Lombard and Parumasur (2017:315) define brand loyalty as a consumer's strong attachment or inner psychological commitment to a brand. Jooste, Strydom, Berndt and Du Plessis (2012:395) and Lamb, Hair, McDaniel, Boshoff, Terblanche, Elliott and Klopper (2013:170) postulate that brand loyalty is the preference or willingness of a consumer to purchase the same brand continuously. Schiffman and Kanuk (2014:65) suggest that brand loyalty consists of two components, namely behaviour, which is the consistency and frequency of buying a particular brand and attitude, which is a consumer's feeling of commitment to a particular brand. Murtiningsih, Moeljadi, Noermijati and Rofiaty (2016:58) postulate that brand loyalty is a lengthy process, which involves consumers learning, through their own direct experiences with purchasing a brand, product and/or service over a period of time, which is consistent and meets and/ or exceeds the expectations of consumers. According to Funk and Levis (2009:51), customer satisfaction is paramount for any organisation that wishes to build loyalty. Keller (2013:1012) indicates that the more satisfied customers are with a particular product, brand and/ or service, the more brand loyal they are believed to be.

Unfortunately, often, there is a gap between customer expectations and what organisations understand regarding those customer expectations (Wilson, Zeithami, Bitner \& Gremler, 
2012:96). As such, for organisations to keep their customers satisfied, they need to bridge this gap.

In South Africa, there are 26 registered public HEls and 106 registered private HEls (National Treasury, 2019; DHET, 2018). Fengu (2019) highlights that the National Students Financial Aid Scheme (NSFAS) is used by the South Africa government as a means to provide R32 billion to a large number of students, enrolled within HEls. Furthermore, South African HEls receive their subsidies from the government, based on the number of new student enrolments they receive each year (Check, 2016). Consequently, HEls need to find a way to capture their share of the total number of students enrolled at both public and private HEls. Based on the current composition of the students enrolled at these public and private HEls in South Africa, the vast majority form part of the Generation $Y$ cohort.

According to Markert (2004:21), the Generation Y cohort constitutes individuals born between 1986 and 2005. For the purpose of this study, the focus will be on students ranging from 18 to 24 years of age. Eder (2013) argues that the Generation $Y$ cohort is difficult to reach and pose an even greater challenge to get the individuals in this cohort engaged. Although the individuals in the Generation $Y$ cohort are known to have clearly defined life goals, wants and fully-formed perceptions towards different brands, products and/ or services, it does not mean that these individuals cannot be brand loyal.

\section{Methodology}

\section{Sampling and data collection}

A descriptive research design was employed in this study. The research methodology chosen for the study was a single-cross sectional sampling approach. The target population for this study were Generation $Y$ students, aged between 18 and 24, currently registered at South African public HEls. From the total of 26 public registered HEls in South Africa, a sampling frame of three HEI campuses was chosen. The three HEls constitute one comprehensive university, one university of technology and one traditional university, which represent the three types of public HEls that are found in South Africa. With the use of a non-probability, convenience sample, combined with a mall-intercept method, 200 questionnaires were distributed to each of the three HEIs to the Generation $Y$ students who were registered on a full-time basis, equalling a total sample size of 600 full-time registered Generation Y students, in the Gauteng province. Included in the questionnaire was a cover letter which clearly outlined the purpose of the study, informing respondents that participation in the study was strictly voluntary.

\section{Research instrument}

A self-administered questionnaire was employed to collect the data required for this study. The fieldworkers explained the nature of the study to the respondents and ensured all respondents that participation was voluntary and that all responses would remain anonymous. The questionnaire constituted two sections, namely Section A, which was used to collect demographic data and Section B, which constituted scaled-response items taken from previously conducted studies. The scales used were adapted and included supportive attitudes (four items) from Sung and Yang (2008:366), relationship commitment (three items) and trust (three items) from Holdford 
and White (1997:256) and students' brand loyalty (three items) from Helgesen and Nesset (2007:132). A six-point Likert scale was used ( $1=$ strongly disagree to $6=$ strongly agree).

\section{Data analysis}

Version 25 of IBM's Statistical Package for Social Sciences (SPSS) and Analysis of Movement Structures (AMOS) was employed in the study to analyse the captured data. Several different statistical techniques were employed to achieve the objectives devised for the study. These statistical techniques employed included descriptive statistics, frequencies, discriminant and convergent validity analysis, composite and internal-consistency reliability analysis, as well as structural equation modelling (SEM).

To determine the internal-consistency reliability of the data sets for this study, the Cronbach alpha statistic was used, where any Cronbach alpha value of above $\geq 0.60$ indicates acceptable internal-consistency reliability and a value of $\geq 0.70$ indicates good to excellent internalconsistency reliability (Zikmund \& Babin, 2013:257; Malhotra, 2010:319). Pearson's Productmoment correlation Coefficient Matrix was used to determine the nomological validity of the data sets. In addition, multicollinearity diagnostics were employed to identify any correlation coefficients between latent factors that may have been high, which was calculated by estimating both tolerance values and variance inflation factors (VIF). Consequently, when tolerance values are lower than 0.10 and VIF values are higher than 10 , multicollinearity is said to be present (Pallant, 2010:156). In order to achieve the research objectives of this study, path analysis using SEM was used, which specified both a measurement and structural model. Furthermore, the standard estimates assessed, the composite reliability (CR) and the average variance extracted (AVE) statistics were employed to determine the reliability and convergent validity of the measurement models. According to Hair, Black, Babin and Anderson (2014:90), a measurement model needs to produce a $\mathrm{CR}$ value of $\geq 0.70$ in order for adequate composite reliability to be achieved. In addition, standardised loading estimates and AVE values exceeding $\geq 0.50$ indicate that convergent validity of a measurement model has been achieved. In conjunction, when the square root value of the AVE exceeds the correlation coefficients, discriminant validity is said to be attained (Hair et al., 2014:631; Byrne, 2010:290-291, Malhotra, 2010:745). To assess the model fit in this study, the following model indices were used, the goodness-of-fit (GFI), the incremental-fix index (IFI), the normed fit index (NFI), the Tucker-Lewis index (TLI) and the comparative fit index (CFI). Malhotra $(2010: 732,747)$ articulates that for a good model fit, model fit indices need to record values of $\geq 0.90$ with regards to RMSEA and with regards to SRMR indices, values of below 0.08 indicate acceptable model fit. Throughout the study, the threshold was set at $p \leq 0.01$ for practical significance.

\section{Findings}

The data collection for this study took place over a two-week period, where trained field workers distributed 600 questionnaires to three HEls (200 per campus) in the Gauteng province. To aid in the representativeness of the sample, the selected HEls consisted of one traditional university, one comprehensive university and one university of technology. Once the data collection was completed, the field workers returned 492 completed questionnaires, indicating an 82 percent response rate. The questionnaires were then screened for any missing values, outliers and any 
irregular responses. Any questionnaire that had more than 10 percent uncompleted was discarded. With regards to missing values, the mode of the missing item was computed and subsequently replaced the missing value. As a result, 480 usable questionnaires remained in the data set, indicating a real-time response rate of 80 percent. The demographics of the sample are represented in Table 1 below: 
Table 1: Demographics

\begin{tabular}{|c|c|c|c|c|c|c|c|c|c|}
\hline Age & $\%$ & Gender & $\%$ & $\begin{array}{c}\text { Province of } \\
\text { origin }\end{array}$ & $\%$ & Year of study & $\%$ & Institution & $\%$ \\
\hline 18 & 4 & Male & 46 & $\begin{array}{l}\text { Eastern } \\
\text { Cape }\end{array}$ & 4 & First year & 32 & Traditional & 35 \\
\hline 19 & 14 & Female & 54 & Free State & 7 & Second year & 30 & Comprehensive & 38 \\
\hline 20 & 26 & & & Gauteng & 64 & Third year & 20 & Technology & 27 \\
\hline 21 & 24 & & & $\begin{array}{l}\text { KwaZulu- } \\
\text { Natal }\end{array}$ & 2 & Fourth year & 14 & & \\
\hline 22 & 20 & & & Limpopo & 12 & Postgraduate & 4 & & \\
\hline 23 & 9 & & & Mpumalanga & 4 & & & & \\
\hline \multirow[t]{3}{*}{24} & 3 & & & $\begin{array}{c}\text { Northern } \\
\text { Cape }\end{array}$ & $<1$ & & & & \\
\hline & & & & North-West & 6 & & & & \\
\hline & & & & $\begin{array}{c}\text { Western } \\
\text { Cape }\end{array}$ & $<1$ & & & & \\
\hline
\end{tabular}

Source: Own work

A representative sample spread can be seen in Table 1 . The majority of the respondents (70\%) were aged in their early 20's, that being from 20 years to 22 years of age. The sample included more females $(54 \%)$ than males $(46 \%)$ and each of the countries nine provinces were represented in the sample. Regarding institutions, the spread was fairly even amongst the three HEIs, with the highest percentage being that of the comprehensive university.

The internal-consistency reliability of the measurement scale was computed by means of the Cronbach alpha statistic. Values of above 0.70 indicate good to excellent internal-consistency reliability (Hair et al., 2014:90; Silver et al., 2013:104; Zikmund \& Babin, 2013:257). The results are depicted in Table 2 below:

Table 2: Summary of reliability test results

\begin{tabular}{lcc}
\hline Constructs & $\begin{array}{c}\text { Number } \\
\text { of items }\end{array}$ & $\begin{array}{c}\text { Cronbach } \\
\text { alpha }\end{array}$ \\
\hline Supportive attitudes & 5 & 0.902 \\
Relationship Commitment & 4 & 0.819 \\
Trust & 4 & 0.799 \\
Brand loyalty & 3 & 0.821 \\
\hline
\end{tabular}

Source: Own work 
Table 2 shows that each of the measurement scale constructs exceeds the 0.70 threshold indicating good internal-consistency reliability. Furthermore, almost all Cronbach alpha values exceeded 0.80, implying excellent reliability. Supportive attitudes received the highest Cronbach value (0.902), whilst trust received the lowest $(0.799)$, which is approaching the excellent value threshold (Hair et al., 2014:90; Zikmund \& Babin, 2013:257; Malhotra, 2010:319). Therefore, it may be safe to assume that the measurement instrument scale represents acceptable internalconsistency reliability.

After the validation of the measuring instruments internal-consistency reliability, descriptive statistics were reported on. Various measures of location, shape and variability were used to analyse the descriptive statistics of each measured item. Furthermore, to assess the significance of the data sets means, a one-sample t-test was employed. Owing to the questionnaire making use of a six-point Likert scale to capture the responses of respondents, an expected mean threshold of 3.50 was set as the benchmark. The significance level was set at $p=0.05$. The means, standard deviations, p-values, skewness and kurtosis values are depicted in Table 3 below.

Table 3: Descriptive statistics

\begin{tabular}{|c|c|c|c|c|c|c|c|}
\hline Constructs & $\mathbf{N}$ & Means & $\begin{array}{l}\text { Standard } \\
\text { deviations }\end{array}$ & t-value & p-value & Skewness & Kurtosis \\
\hline $\begin{array}{l}\text { Supportive } \\
\text { attitudes }\end{array}$ & 480 & 4.345 & 1.162 & 81.917 & 0.000 & -0.841 & 0.194 \\
\hline $\begin{array}{l}\text { Relationship } \\
\text { Commitment }\end{array}$ & 480 & 4.427 & 1.089 & 89.016 & 0.000 & -0.950 & 0.646 \\
\hline Trust & 480 & 4.625 & 0.882 & 114.904 & 0.000 & -0.949 & 1.843 \\
\hline Brand loyalty & 480 & 4.324 & 1.289 & 73.496 & 0.000 & -0.791 & 0.046 \\
\hline
\end{tabular}

As can be seen in Table 3, all measured constructs achieved means higher than the specified 3.50 threshold. In addition, the means of each construct were statistically significant at the $p \leq$ 0.05 level. These results suggest that Generation $Y$ students display both positive attitudes and relationship commitment towards staying brand loyal to their current HEI. Furthermore, this cohort feels that their HEI is trustworthy and these individuals feel brand loyal towards their HEI. In terms of the shape and normality of the data, skewness values fell in the recommended range of -2 and +2. Furthermore, no irregularities were present in the kurtosis values (Berndt \& Petzer, 2011:218).

The data sets nomological validity was asserted using the Pearson's product-moment correlation coefficient. To determine if any multicollinearity was present between the latent factors, collinearity diagnostics were undertaken. The Pearson correlation matrix is presented in Table 4. 
Table 4: Correlation analysis

\begin{tabular}{lllll}
\hline Constructs & $\mathbf{1}$ & $\mathbf{2}$ & $\mathbf{3}$ & $\mathbf{4}$ \\
\hline Supportive attitudes & 1 & & & \\
Relationship Commitment & $0.698^{\star *}$ & 1 & & \\
Trust & $0.572^{\star *}$ & $0.611^{\star *}$ & 1 & \\
Brand loyalty & $0.706^{\star *}$ & $0.729^{\star *}$ & $0.530^{\star *}$ & 1 \\
\hline
\end{tabular}

${ }^{\star \star}$ Correlation is significant at the $\mathbf{0 . 0 1}$ level (2-tailed).

Source: Own work

As can be seen in Table 4, each pair of latent factors represents a statistically positive significant ( $p \leq 0.01$ ) association between each other. Owing to the significant relationships amongst the latent factors, it may be inferred that nomological validity is present for the proposed model. Each of the correlations were categorised as strong relationships as all values were above 0.50 (Pallant, 2010:135; Cohen, 1992:158). The strongest associated latent factors were that of relationship commitment and brand loyalty $(r=0.729)$, followed by supportive attitudes and brand loyalty $(r=0.706)$. These are valuable results and are in line with prior research findings (Giovanis \& Athanasopoulou, 2017; Erdogmusa \& Ergun, 2016; Gozukara \& Colakoglu, 2016). The two lowest relationships were that of supportive attitudes and trust $(r=0.572)$ and trust on brand loyalty $(r=0.530)$. With regards to collinearity diagnostics, the following results were computed. The tolerance values of the independent variable equalled to 0.511 and obtained an average VIF of 1.956. Thus, it may be assumed that the data set had no multicollinearity issues (Pallant, 2013:164). To conclude, no multicollinearity concerns were present and with nomological validity established, it was presumed safe to proceed with the SEM analysis.

To confirm the items of the latent factors, a confirmatory factor analysis, using the maximum likelihood approach, was undertaken in the measurement model. The first loadings of each factor were set at the fixed standard value of 1.0, the model then calculated 91 sample moments and 32 parameters to be estimated. Consequently, 59 degrees of freedom were specified, with a significant chi-square of $152.481(p=0.000)$ based on an over identified model. The measurement model is depicted in Figure 1. 
Figure 1: Measurement model

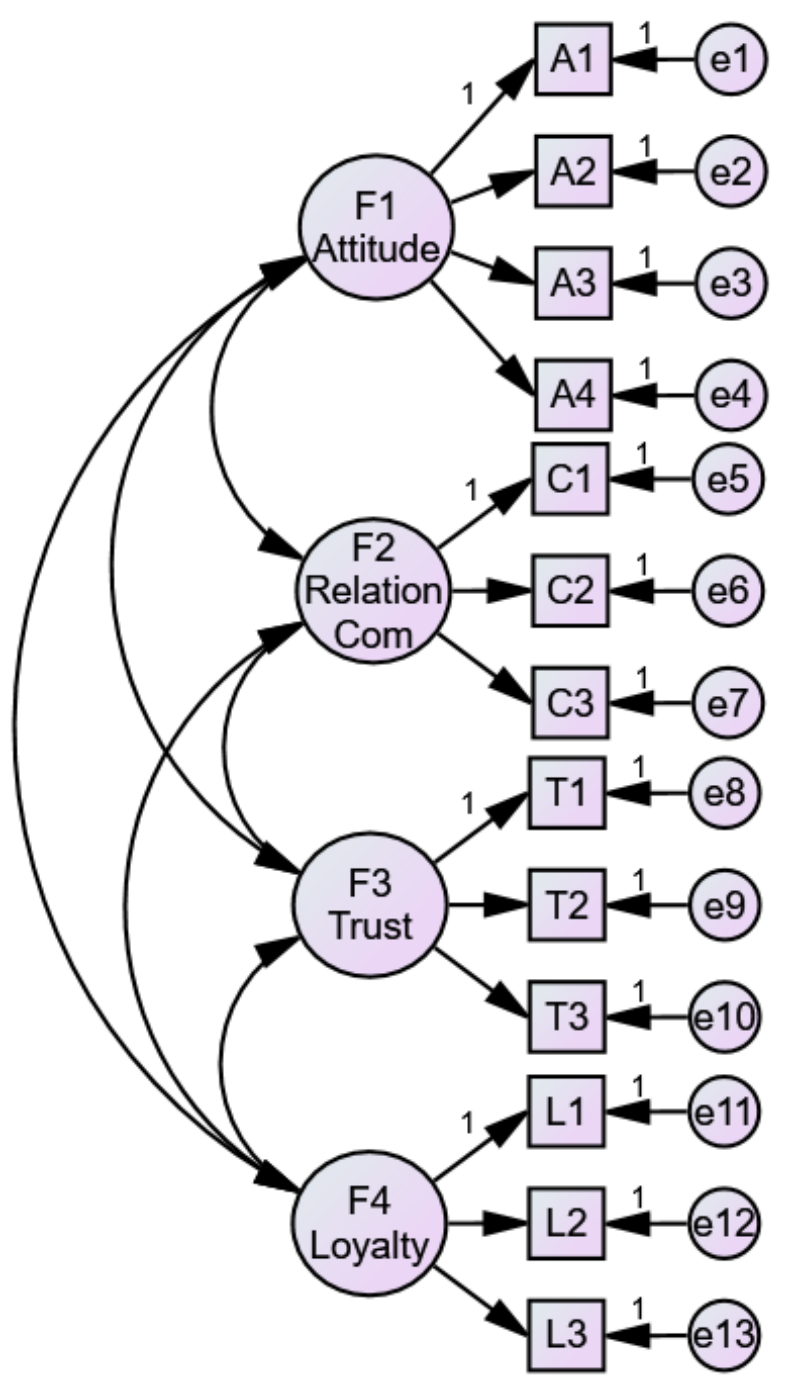

Source: Own work

The measurement model computed no problematic estimates as all standardised estimates were not above 1.0 or below -1.0. Furthermore, there was no evidence of Heywood cases (no negative error variances) (Hair et al., 2014:618). The standardised loading estimates, error variance estimates, CR values, AVE values, square root of the AVE values ( $\mathrm{AVVE}$ ) and the correlation coefficients are reported in Table 5. 
Table 5: Measurement Model Estimates

\begin{tabular}{|c|c|c|c|c|c|}
\hline Latent factors & $\begin{array}{c}\text { Standardised } \\
\text { loading } \\
\text { estimates }\end{array}$ & $\begin{array}{c}\text { Error } \\
\text { variance } \\
\text { estimates }\end{array}$ & CR & AVE & $\sqrt{ }$ AVE \\
\hline \multirow{4}{*}{$\begin{array}{l}\text { Supportive attitudes } \\
\text { (F1) }\end{array}$} & 0.768 & 0.590 & \multirow[t]{4}{*}{0.80} & \multirow[t]{4}{*}{0.51} & \multirow[t]{4}{*}{0.72} \\
\hline & 0.900 & 0.811 & & & \\
\hline & 0.797 & 0.634 & & & \\
\hline & 0.884 & 0.781 & & & \\
\hline \multirow{3}{*}{$\begin{array}{l}\text { Relationship } \\
\text { commitment (F2) }\end{array}$} & 0.831 & 0.690 & \multirow[t]{3}{*}{0.75} & \multirow[t]{3}{*}{0.51} & \multirow[t]{3}{*}{0.72} \\
\hline & 0.809 & 0.654 & & & \\
\hline & 0.718 & 0.516 & & & \\
\hline \multirow[t]{3}{*}{ Trust (F3) } & 0.803 & 0.645 & \multirow[t]{3}{*}{0.75} & \multirow[t]{3}{*}{0.50} & \multirow[t]{3}{*}{0.71} \\
\hline & 0.809 & 0.654 & & & \\
\hline & 0.681 & 0.463 & & & \\
\hline \multirow[t]{4}{*}{ Brand loyalty (F4) } & 0.792 & 0.628 & \multirow[t]{4}{*}{0.75} & \multirow[t]{4}{*}{0.50} & \multirow[t]{4}{*}{0.71} \\
\hline & 0.771 & 0.594 & & & \\
\hline & 0.783 & 0.614 & & & \\
\hline & $\mathrm{F} 1 \leftrightarrow \mathrm{F} 2: 0.79$ & $\mathrm{~F} 2 \leftrightarrow \mathrm{F} 3: 0.71$ & & & \\
\hline \multirow[t]{2}{*}{ Correlations } & $\mathrm{F} 1 \leftrightarrow \mathrm{F} 3: 0.63$ & $\mathrm{~F} 2 \leftrightarrow \mathrm{F} 4: 0.81$ & & & \\
\hline & $\mathrm{F} 1 \leftrightarrow \mathrm{F} 4: 0.82$ & $\mathrm{~F} 3 \leftrightarrow \mathrm{F} 4: 0.62$ & & & \\
\hline
\end{tabular}

Source: Own work

All $C R$ values exceed the recommended 0.70 cut-off value, thus, inferring composite reliability for the measurement model. Additionally, all AVE values surpassed the threshold of 0.50 , indicating convergent validity. The square root of the AVE for the independent variables exceed the correlations between $\mathrm{F} 1 \leftrightarrow \mathrm{F} 2(0.69>0.72)$. As such, discriminant validity was confirmed (Hair et al., 2014:620). Owing to the significant chi-square statistic (known for being sensitive to large sample sizes), other incremental fit indices were computed in order to ascertain if the model achieved a good fit. The results include NFI $=0.961, \mathrm{IFI}=0.976, \mathrm{TLI}=0.968, \mathrm{CFI}=0.976, \mathrm{SRMR}$ $=0.044$ and a RMSEA of 0.058 .

After the measurement model was confirmed and a good fit attained, a structural model was then adopted to determine the effects of the underlying relationships between the latent variables. The structural model sought to investigate the effect of the independent variables of supportive attitudes (F1) and relationship commitment (F2) influences on Generation Y students' trust (F3) towards their current $\mathrm{HEl}$. Additionally, the model intended to explore if the nature of trust (F3) has a direct significant positive effect towards HEI brand loyalty (F4) of Generation Y students. The proposed structural model is depicted in Figure 2. 
Figure 2: Proposed structural model

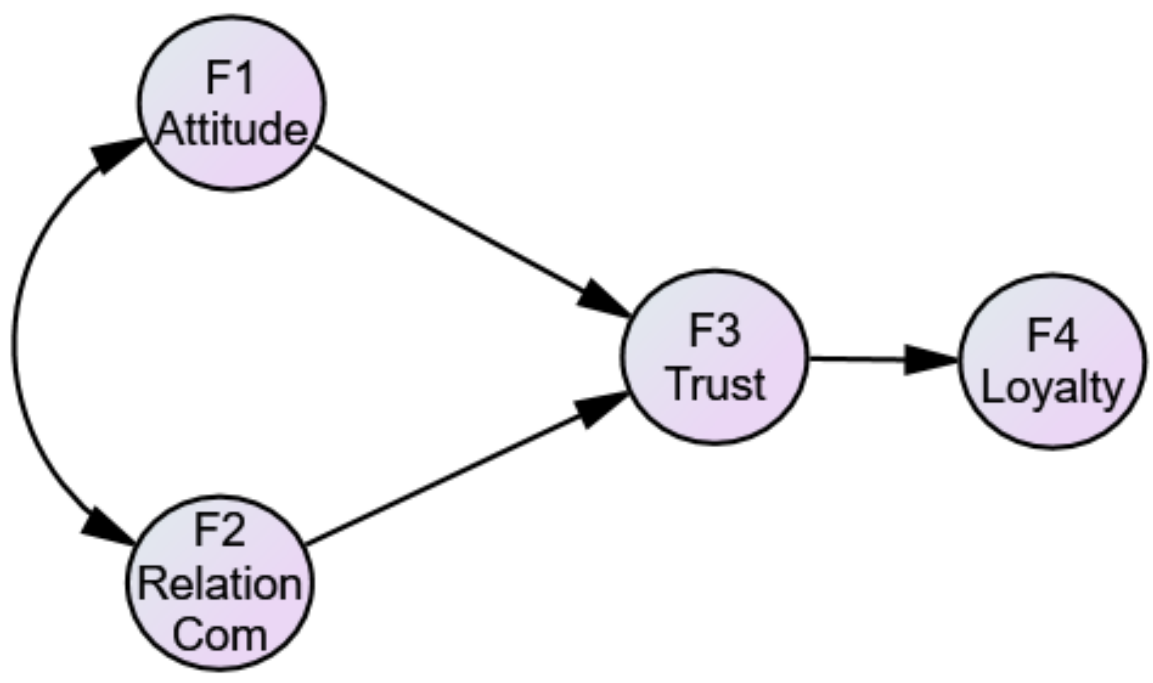

Source: Own work

Once again, the structural model returned a significant chi-square value. As such, the other fit indices were inspected to confirm the models fit. These included a NFI of 0.921 , a IFI of 0.935 , a TLI of 0.917 , a CFI of 0.935 , a SRMR of 0.053 and a RMSEA of 0.093 . Kenny, Kaniskan, \& McCoach (2015:501) state that the RMSEA statistic can be sensitive and regularly exceed cut-off points when the sample size has small degrees of freedom $(d f \approx 50)$. As this is the case for this study $(d f=59)$, it is not surprising that the RMSEA value fell out of the good range $(>0.08)$ into the moderate range $(<0.1)$ (Cangur \& Ercan, 2015:157; Kenny et al., 2015:487). Furthermore, the SRMR value is well below the 0.08 cut-off and displays a good fit for the model. The path model analysis results of the structural model are presented in Table 6 . These results include the standardised regression coefficients, standard error estimates and $p$-values as estimated for the structural model by AMOS.

Table 6: Standardised regression estimates and p-values

\begin{tabular}{llll}
\hline Relationship & Estimates & $\mathbf{p}$-value & Results \\
\hline Supportive attitudes $\rightarrow$ Trust & 0.289 & $0.000^{* *}$ & Significant \\
Relationship commitment $\rightarrow$ Trust & 0.697 & $0.000^{* *}$ & Significant \\
Trust $\rightarrow$ Brand loyalty & 0.902 & $0.000^{* *}$ & Significant \\
\hline${ }^{* \star}$ Significant at the $\mathbf{p}<\mathbf{0 . 0 1}$ level & & & \\
\hline Source: Own work & & &
\end{tabular}

As Table 6 shows, all tested paths were positively statistically significant $(p \leq 0.01)$. Supportive attitudes $(\beta=0.289, p<0.01)$ and relationship commitment $(\beta=0.697, p<0.01)$ are statistically significant predictors of Generation Y students' trust in their HEls. In addition, trust $(\beta=0.902, p<$ 0.01 ) has a significant positive influence on brand loyalty of Generation Y students. Regarding the squared multiple correlation coefficients, supportive attitudes and relationship commitment 
explained 89 percent of the variance in Generation $Y$ students' trust towards their HEls, which in turn, explained 81 percent of the variance towards their brand loyalty intentions of their HEls. The structural model with the path estimates is presented in Figure 3.

Figure 3: Structural model of university students' brand loyalty

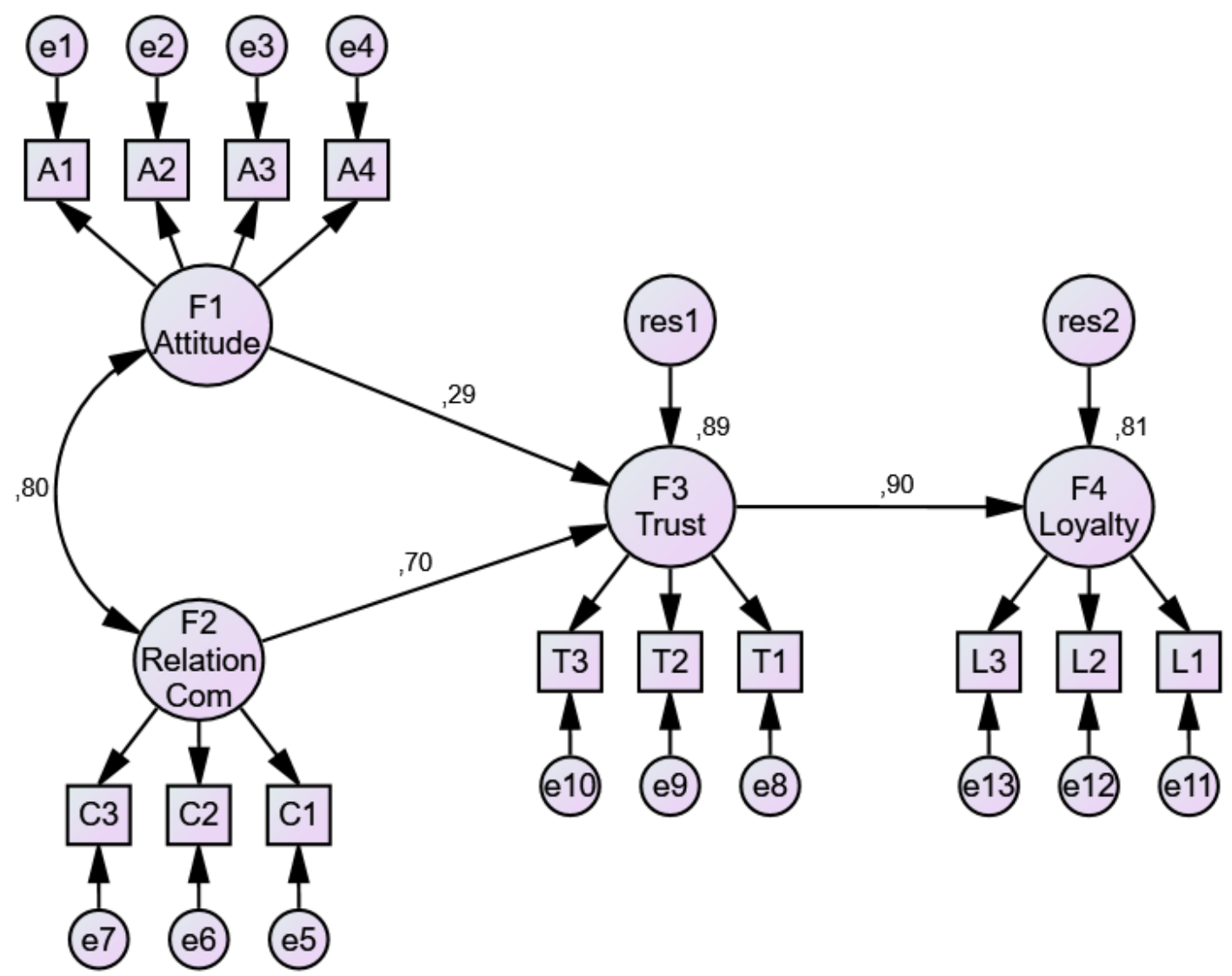

Source: Own work

The works of Hidayanti, Nuryakin and Farida (2018:276), Giovanis and Athanasopoulou, (2017), Erdogmusa and Ergun (2016) and Gozukara and Colakoglu (2016) concur with the results found in this study.

\section{Conclusion}

The higher education market has become rife with competition, as a result, student loyalty has never been a more important factor to consider to date than it is now (Giner \& Rillo, 2016:258). The purpose of this study sought to determine the influence supportive attitude, relationship commitment and trust have on Generation $Y$ students' brand loyalty towards their HEls. This was done by means of building a relationship model built on brand loyalty theoretical literature. The model was affirmed through structural equation modelling, using participant data gathered from 480 Generation $Y$ students at three HEls in the Gauteng province of South Africa. The findings of this study indicated that supportive attitudes and relationship commitment displayed a positive 
influence on students' trust in their HEls. Additionally, this trust then influenced students' intentions to become brand loyal constituents and/or brand advocates of their current HEI.

The study found that relationship commitment was a key determinant of students' trust, which constitutes the desire to maintain a valuable relationship, be it between individuals or an organisation. Whilst, supportive attitudes may not have had as a strong effect as relationship commitment, it still displayed a positive influence on students' trust. The impact of relationship commitment was almost triple that of supportive attitudes on HEI trust. This finding indicates that Generation $Y$ students perceive the relationship between them and their HEls as more important when building a trustful relationship between them and the HEI. These results build on the trustcommitment theory, wherein high levels of commitment and trust are instrumental in promoting both cooperative behaviours and building successful long-term relationships (Lang, 2016; van Vuuren, Roberts-Lombard \& van Tonder, 2012:83). These results are in line with the prior work undertaken by Holdford \& White (1997:250). Additionally, this study determined that the trust of Generation $\mathrm{Y}$ students had a large significant influence on HEI brand loyalty. Consequently, trust is a highly influential factor towards brand loyalty, which has been investigated in a number of studies, such as Lee et al. (2015:301), Liao (2015:603) and Nawaz and Usman (2011:219). Consequently, HEls should then entice both prospective and current students by implementing strategies that (1) promote positive attitudes, (2) build commitment-trust relationships, and (3) focus on strengthening trust in order to maintain long-term brand loyal relationships.

Generation $Y$ students were found to be brand loyal to their HEls in this study. This is a vital finding, as loyal alumni may become noteworthy ambassadors of their prior institutions (Ali et al., 2016:75). This loyalty can potentially transgress into an HEI being adopted as a family's chosen institute, meaning parents may opt to send their offspring to the same higher education institution which they have graduated from. This is more likely to occur if some form of commitment-trust relationship has taken place, installing brand loyalty into an individual (Hinds, 2017). Furthermore, creating a positive attitude may lead to favourable brand loyalty and behaviour, thus leading to possible funding from alumni and positive word-of-mouth for HEls. In the long-run, this will bode well for any HEI in a financial manner, while allowing HEls the freedom to be selective as to whom it admits into the institution.

\section{Limitations and future research}

Every study is bound by some form of limitation and this study is no exception. This study made use of a non-probability sampling method to collect the necessary data. When generalising results to a population, it is advisable to proceed with caution, despite precautionary measures being implemented. For this study, screening demographic questions and the judgement of the researchers were employed. Despite being used repeatedly in many studies, a cross-sectional design only provides a single snapshot in time and lacks the robustness of a longitudinal study. This study used a cross-sectional design which focused solely on participants situated in the Gauteng province.

Future research in this topic can be narrowed down into many facets. A few alternative perspectives may include sectioning out the different departments of HEls or perhaps comparing HEIs located in different geographical locations. In addition, the study may be broadened by 
implanting other factors known to influence brand loyalty. These may include but are not limited to imagery, satisfaction, HEI brand personality or HEI feelings. To conclude, this study may be replicated to include other tertiary institutions available in South Africa. These include private HEls, colleges and further education and training (FET) institutions.

\section{References}

ABBAS, S.A. (2019). Brand Loyalty of Higher Education Institutions. Marketing and Management of Innovations, 1:46-56.

AHMED, Z., RIZWAN, M., AHMAD, M. \& HAQ, M. (2014). Effect of brand trust and customer satisfaction on brand loyalty in Bahawalpur. Journal of Sociological Research, 5(1):306-326.

AJZEN, I. \& FISHBEIN, M. (1977). Attitude-Behavior Relations: A Theoretical Analysis and Review of Empirical Research. Psychological Bulletin, 84(5): 888-918.

AJZEN, I. (1991). The Theory of Planned Behavior. Organizational Behaviour and Human Decision Processes, 50(2): 179-211.

ALI, F., ZHOU, Y., HUSSAIN, K., NAIR, P.K. \& RAGAVAN, N.A. (2016). Does higher education service quality effect student satisfaction, image and loyalty: A study of international students in Malaysian public universities. Quality Assurance in Education, 24(1):70-94.

ALVES, H. \& RAPOSO, M. (2010). The influence of university image on student behaviour. International Journal of Educational Management, 24(1): 73-85.

ARITONANG, R. AND LERBIN, R. (2014). Student loyalty modelling. Market-Tržište, 26(1):77-91.

BAKER, M.J. (2001). Marketing Critical Perspectives on Business and Management. London \& New York: Routledge.

BERNDT, A. \& PETZER, D. (2011). Marketing research. Pinelands, Cape Town: Heinemann.

BEVAN-DYE, A.L. \& SURUJLAL, J. (2011). Attitudes towards materialism in sport and materialism tendencies amongst Black Generation Y students. African Journal for Physical, Health Education, Recreation and Dance, 17(4), 43-55.

BYRNE, B.M. (2010). Structural Equation Modelling with AMOS: Basic Concepts, Applications, and Programming. $2^{\text {nd }}$ ed. New York, NY: Taylor \& Francis Group.

CANGUR, S. \& ERCAN, I. (2015). Comparison of model fit indices used in structural equation modeling under multivariate normality. Journal of Modern Applied Statistical Methods, 14 (1). 152-167.

CHECK, A. (2016). FACTSHEET: Funding and the changing face of South Africa's public universities. https://africacheck.org/factsheets/factsheet-funding-changing-face-sas-public-universities/ Date of access: 12 June 2019.

COHEN, J. (1992). A Power Primer. Psychological Bulletin, 112(1):155-162.

DHET. (2018). Register of private higher education institutions.

https://cach.dhet.gov.za/files/RegisterOfPrivateHigherEducationInstitutions.pdf Date of access: 12 June 2019. 
EDER, J. (2013). Are students becoming more brand loyal? https://www.theguardian.com/medianetwork/media-network-blog/2013/aug/16/students-youth-brand-entertainment-loyalty Date of access: 1 September 2019.

ERDOGMUSA, I. \& ERGUN, S. (2016). Understanding university brand loyalty: the mediating role of attitudes towards the department and university. Procedia - Social and Behavioral Sciences. 229:141 -150 .

FENGU, M. (2019). Nsfas to disburse R32bn next year, eligible students to be notified in January. https://city-press.news24.com/News/nsfas-to-disburse-r32-billion-next-year-eligible-students-to-benotified-in-january-20181227 Date of access: 12 June 2019.

FISHBEIN, M. \& AJZEN, I. (1975). Belief, Attitude, Intention, and Behaviour: An Introduction to Theory and Research. Reading, MA: Addison-Wesley.

FUNK, D. \& LEVIS, A.M. (2009). Conscious branding. New York: Business Expert Press.

GINER, G.R. \& RILLO, A.P. (2016). Structural equation modelling of co-creation and its influence on the student's satisfaction and loyalty towards university. Journal of Computational and Applied Mathematics, 291: 257-263.

GIOVANIS, A. \& ATHANASOPOULOU, P. (2017). Gen Y-ers' brand loyalty drivers in emerging devices. Marketing Intelligence \& Planning, 35(6): 805-821

GOZUKARA, I. \& COLAKOGLU, N. (2016). A research on Generation Y students: brand innovation, brand trust and brand loyalty. International Journal of Business Management and Economic Research, 7(2): 603-611.

HAIR, J., BLACK, W., BABIN, B. \& ANDERSON, R. (2014). Multivariate Data Analysis. 7th ed. Harlow, Essex: Pearson.

HANSSEN, T.S. \& SOLVOLL, G. (2015). The importance of university facilities for student satisfaction at a Norwegian University. Facilities, 33(13/14):744-759.

HELGESEN, O. \& NESSET, E. (2007). What accounts for students' loyalty? Some field study evidence. International Journal of Educational Management, 21(2):126-143.

HIDAYANTI, I., NURYAKIN \& FARIDA, N. (2018). A study on brand commitment and brand trust towards brand loyalty of branded laptop in Indonesia. Journal of Business and Retail Management Research (JBRMR), 12(3):270-278.

HINDS, T. (2017). Brand Loyalty Advice for Higher Education Leaders. https://www.insidehighered.com/blogs/call-action-marketing-and-communications-highereducation/brand-loyalty-advice-higher. Date of access: 1 September 2019.

HOLFORD, D. \& WHITE, S. (1997). Testing Commitment- Trust Theory in Relationships Between Pharmacy Schools and Students. American Journal of Pharmaceutical Education, 61: 249-256.

JOOSTE, C.J., STRYDOM, J.W., BERNDT, A. \& DU PLESSIS, P.J. (2012). Applied strategic marketing. 4th ed. Cape Town: Pearson.

KELLER, K.L. (2013). Strategic Brand Management: Building, Measuring, and Managing Brand Equity 4th global ed. Essex: Pearson. 
KENNY, D. A., KANISKAN, B. \& MCCOACH, D.B. (2015). The performance of RMSEA in models with small degrees of freedom. Sociological Methods \& Research, 44 (3). 486-507.

KOTHARI, A. (2019). Customer Value: What It Means and How to Create It [5+ Ideas]. https://tallyfy.com/customer-value/. Date of access: 5 September 2019.

LAMB, C.W., HAIR, J.F., MCDANIEL, C., BOSHOFF, C., TERBLANCHE, N., ELLIOTT, R. \& KLOPPER, H. B. (2013). Marketing. 4th Ed. Cape Town: Oxford University Press.

LANG, S. (2016). What is customer commitment? www.clicktools.com/what-is-customer-commitment. Date of access: 5 September 2019.

LEE, D., MOON, J., KIM, Y.J. \& YI, M.Y. (2015). Antecedents and consequences of mobile phone usability: Linking simplicity and interactivity to satisfaction, trust, and brand loyalty. Information \& Management, 52 (1). 295-304.

LIAO, Y.K. (2015). The role of trust on brand loyalty and brand equity. Managing Intellectual Capital and Innovation for Sustainable and Inclusive Society, Management, Knowledge and Learning Joint International Conference 2015, 603-612. http://www.toknowpress.net/ISBN/978-961-6914-130/papers/ML15-121.pdf Date of access: 10 September 2019.

MALHOTRA, K. N. (2010). Marketing research: an applied orientation. 6th ed. Upper Saddle River, N.J: Pearson Education.

MARKERT, J. (2004). Demographics of age: generational and cohort confusion. Journal of Current Issues and Research in Advertising, 26 (2):11-25.

MPINGANJIRA, M., DOS SANTOS, M.A.O., BOTHA, E., DU TOIT, D., ERASMUS, A., MAREE, T. \& MUGOBO, V. (2014). Consumer Behaviour: South African Psychology and Marketing Application. Cape Town, South Africa: Oxford.

MURTININGSIH, D. (2016). The Effect of Brand Trust and Brand Loyalty (Studies in the university of Budi Luhur Jakarta). International Journal of Business, Economics and Law, 11(2):57-61.

NATIONAL TREASURY. (2019). Budget Review 2019.

http://www.treasury.gov.za/documents/national\%20budget/2019/review/FullBR.pdf. Date of access: 12 June 2019.

NAWAZ, N.U.A. \& USMAN, A. (2011). What Makes Customers Brand Loyal: A Study on Telecommunication Sector of Pakistan. International Journal of Business and Social Science, 2(14):213-221.

NOBLE, S.M., HAYTKO, D.L. AND PHILLIPS, J. (2009). What drives college-age Generation Y consumers? Journal of Business Research, 62(6):617-628.

PALLANT, J. (2010). SPSS survival manual: a step by step guide to data analysis using SPSS. $4^{\text {th }}$ ed. England: Open University Press.

PALLANT, J. (2013). A step by step guide to data analysis using IBM SPSS: SPSS survival manual. $5^{\text {th }}$ ed. Maidenhead: Open University/McGraw-Hill. 
PETRUZZELLIS, L. \& ROMANAZZI, S. (2010). Educational value: how students choose university: Evidence from an Italian university. International Journal of Educational Management, 24(2): 139158.

RENGEL V.K., RAMIREZ, M.E. \& BENAVIDES, A.V. (2017). Analysis of communication factors influencing customer loyalty among university students. Revista Latina de Comunicación Social, 72: 751-764.

ROBERTS-LOMBARD, M. \& PARUMASUR, S.B. (2017). Consumer Behaviour. $4^{\text {th }}$ ed. Cape Town, South Africa: JUTA.

SCHIFFMAN, L. \& KANUK, L. (2014). Global and Southern African Perspectives Consumer Behaviour. Cape Town, South Africa: Pearson.

SETYAWAN, A.A. (2015). Brand trust and brand loyalty, an empirical study in Indonesia consumers. British Journal of Marketing Studies, 4(3):37-47.

SILVER, L., STEVENS, R., WRENN, B. \& LOUDON, D. (2013). The essentials of marketing research. $3^{\text {rd }}$ ed. USA, NY: Routledge, Taylor \& Francis Group.

SIMSON, N. (2019). What is brand trust and why is it so important? https://naomisimson.com/2-businessadvice/business-advice/what-is-brand-trust-AND-WHY-IS-IT-SO-IMPORTANT/ Date of access: 4 September 2019.

SPACEY, J. (2018). Types of Customer Benefits. https://simplicable.com/new/customer-benefits Date of access: 5 September 2019.

SUNG, M. \& YANG, S. (2008). Toward the model of university image: the influence of brand personality, external prestige, and reputation. Journal of Public Relations Research, 20(4):357376.

THOMAS, S. (2011). What drives student loyalty in universities: An empirical model from India. International Business Research, 4(2):183-192.

VAN VUUREN, T., ROBERTS-LOMBARD, M. \& VAN TONDER, E. (2012). Customer satisfaction, trust and commitment as predictors of customer loyalty within an optometric practice environment. South African Business Review, 16(3):81-96.

WILSON, A., ZEITHAML, V.A., BITNER, M.J. \& GREMLER, D.D. (2012). Services marketing: Integrating customer focus across the firm. Maidenhead: McGraw Hill.

ZIKMUND, G.W. \& BABIN, J.B. (2013). Essentials of marketing research. $5^{\text {th }}$ ed. South-Western, Cengage Learning. 